\title{
Effect of the Regrowth Age on the Chemical Composition, Digestibility and Polyphenol Content of Jatropha Curcas
}

\author{
Verdecia DM ${ }^{1 *}$, Torres $E^{2}$, Sánchez $\mathrm{AR}^{2}$, Álvarez-PerdomoGR ${ }^{2}$, Herrera RS ${ }^{3}$, Ramirez JL ${ }^{1}$, Paumier $\mathbf{M}^{1}$, Bodas $\mathrm{R}^{4}$, Giraldez FJ ${ }^{5}$, \\ Grizelj J ${ }^{6}$ and Lopez $S^{7}$
}

${ }^{1}$ Animal Production Study Center, University of Granma, Cuba

${ }^{2}$ Technical State University of Quevedo, Extension La María, Mocacha-Los Ríos, Ecuador

${ }^{3}$ Institute of Animal Science, Cuba

${ }^{4}$ ITACYL Agricultural Technological Institute, Spain

${ }^{5}$ Mountain Livestock Institute (CSIC-ULE), Spain

${ }^{6}$ University of Zagreb, Faculty of Veterinary Medicine, Croatia

${ }^{7}$ Animal Production Department, University of León, Spain

*Corresponding author: Verdecia DM, Animal Production Study Center, University of Granma, PO Box 21, Bayamo, C.P. 85 100, Granma, Cuba

\begin{abstract}
The present work was developed with the objective of evaluating the effect of the regrowth age on the chemical composition, digestibility and polyphenol content of the Jatropha curcas in an area of Cauto Valley. Was used piece of ground of Jatropha curcas with two years of establishment. A randomized block design with six replicas was used. The treatments were regrowth ages of 60, 120 and 180 days. At the beginning of each seasonal period a homogeneity cut was made at $1 \mathrm{~m}$ above the ground level. From there the sampling was carried out in 10 random plants eliminating the edge effect in an area of $0.5 \mathrm{ha}$, according to the treatments. The chemical composition of Jatropha curcas the dry matter content, DNF, ADF, ADL, increase with age with its best results at 180 days with 28.82; 51.53; 33.44 and 20.22\%; while the CP and cellular content decrease with its highest results at 60 days 27.78 and $58.79 \%$. The minerals showed a very variable behavior. The highest energy contribution and digestibility percentage at 60 days of age with a decrease of 11.04; 7.40; 8.90\%; 1.58 and $1.11 \mathrm{MJ} / \mathrm{kg}$. Polyphenolic compounds increase with age with the best results at 180 days of age with $11.26,21.10,113.93,111.49$ and $2.46 \mathrm{~g} / \mathrm{Kg}$, respectively; for total tannins, total phenols, TCT, TBCT and FTC. The results of the present investigation evidenced the marked effect of climatic factors and age on the quality of the Jatropha curcas, as the maturity of the forage progressed, its nutritional contribution decreased with a decrease in the $\mathrm{CP}$, the nutrient content, digestibility and energy, as well as an increase in the fibrous fraction and the content of polyphenolic compounds.
\end{abstract}

\section{Introduction}

Due to the food deficit and the global economic crisis, Latin American countries have had to venture into other feeding strategies to increase animal production in tropical conditions, by supplying livestock with more protein and minerals, which in general are found deficit in grasses Diaz. In this sense, the biomass of trees, shrubs have a leading role for their considerable protein levels and acceptable nutritional value. Due to the perspectives and benefits of this plant for tropical livestock, it is necessary to know the essential characteristics of its chemical composition, nutritional value and its impact on the acceptability of the animal Boufennara et al. [1]. The presence of foliage of trees, shrubs and legumes in animal diets, whether in fresh or flour form, can improve production yields, which represents a practical and economical alternative to increase productivity in developing countries Boufennara et al. [1]. Most of these food sources have a well-balanced amino acid pattern in relation to the established requirements, so the total protein required in the diet is much lower than when cereals are the basis of it, and the waste is less of nitrogen during metabolism 
Murgueitio et al. [2]. Among these tree species is Jatropha curcas with outstanding nutritional qualities, rich in protein, vitamins and minerals, it is a multipurpose species, of tropical origin, belonging to the Euphorbiaceae family and their common names vary according to the different regions where it is grown. In Cuba it is recognized as: pinija pinion, fence pinion, purgative pinion; It is called piñoncillo in Mexico, piñol in Peru and tempate in Costa Rica. It can grow both in areas of high and low annual rainfall. It is fast growing and seed production can begin even in the first year of planting. Highly resistant to drought, it can be grown in marginal areas, without competing with the production of species for human consumption Toral et al. [3]. According to the above mentioned, the aim of this work was to evaluate the effect of the regrowth age on the chemical composition, digestibility and polyphenol content of Jatropha curcas in an area of the Cauto Valley.

\section{Material and Methods}

\section{Geographic LOCATION}

The research was carried out by the Productive Teaching Department of Granma University (Granma, Cuba). An area of 4410 $\mathrm{m} 2$ was used for the purposes of this experiment from 2007 to 2009. The type of soil was calcic haptustept Soil Survey Staff [4], with $\mathrm{pH}$ 6.2. The $\mathrm{P}_{2} \mathrm{O}_{5}, \mathrm{~K}_{2} \mathrm{O}$ and $\mathrm{N}$ total content was $2.4,33.4$ y 3.0 $\mathrm{mg} / 100 \mathrm{~g}$ of soil, respectively, with $3.6 \%$ of organic matter.

\section{Treatments and experimental design}

According to weather conditions, the period of study was divided in two seasons: rainy season (May-October) and dry season (November-April). The rainfall during the rainy season was $894 \mathrm{~mm}$, the mean, minimum and maximum temperatures registered were $26.7,22.3$ and $33.9{ }^{\circ} \mathrm{C}$, respectively and the mean, minimum and maximum relative humidity were 80.8, 51.0 and $99.2 \%$, respectively. The rainfall during dry season was $364 \mathrm{~mm}$; the mean, minimum and maximum temperatures were $24.5,18.3$ and $31.6{ }^{\circ} \mathrm{C}$, respectively, and the mean, minimum and maximum relative humidity were $76.2,44.2$ and $97.0 \%$, respectively. Within each season, three regrowth ages were considered: 60,120 and 180 days; thus, the development state varied from a vegetative growing state at 60 days up to flowering at 180 days. A random block design with three replicates per block was used ( 9 plots of $396 \mathrm{~m}^{2}$ ).

\section{Experimental procedure}

At the beginning of each season, the plants were trimmed $1 \mathrm{~m}$ above ground level. Later on, at each regrowth age, 10 plants were randomly selected from each plot at every regrowth age, discarding the lowest and highest plants. Stalk and petioles with diameters inferior to $2 \mathrm{~cm}$ were chosen (considered, as a whole, the useful biomass to be eaten by animals). All select materials were mixed and a homogenous sample representative of useful biomass was obtained. This sample was dried at $65^{\circ} \mathrm{C}$ in a forced-air circulation oven for 72 hours, in order to determine the dry matter content (DM). Once dried, samples were stored in a dry cool place until further analyses.

\section{Chemical analysis}

Neutral detergent fiber (NDF), acid detergent fiber (ADF) and acid detergent lignin (ADL) contents were determined according to Goering and Van Soest [5]. AOAC [6] procedures were used to determine crude protein $(\mathrm{CP})$, ash, organic matter $(\mathrm{OM})$ and minerals (calcium, phosphorus, magnesium and silica) contents. Phenolic compounds were extracted and analyzed following the procedures described by Makkar [7]. Total extractable phenols (TP) were determined using the Folin-Ciolateau reagent and tannic acid as standard. Total extractable tannins(TT)were estimated after adsorption of TP to insoluble polyvinylpyrrolidone, and measuring the remaining total phenols in the supernatant (or nonprecipitable phenols). Concentration of total extractable tannins (TT) was calculated through subtraction as follows TT = TP - nonprecipitable phenols. Free condensed tannins (FCT) were measured in the extract using the butanol- $\mathrm{HCl}$ assay Porter et al. with the modifications of Makkar [7]. Total condensed tannins attach (TCTA) were measured in the solid residue remaining after extraction of phenolic compounds. Concentration of total condensed tannins (TT) was calculated as follows: TT $=$ FCT + CTA. Concentration of phenols and tannins were expressed in g tannic acid equivalent $\mathrm{kg}-1 \mathrm{DM}$.

\section{In vitro digestibility}

In vitro dry matter digestibility (IVDMD) was determined by the ANKOM procedure, using a Daisy II ${ }^{\circledR}$ incubator (ANKOM Technology, Fairport, NY-USA), as described by Robinson et al. [8]. Rumen fluid obtained from four canulated sheep was diluted $(1: 4 \mathrm{v} / \mathrm{v})$ into the medium as reported by Menke and Steingass [9]. Four Merino sheep were provided permanent ruminale cannula, with weight lives off 53,8 $\pm 4,08 \mathrm{~kg}$, housed in cubicles singular, consumed during the experiment medic hay (Medicago sativa) and Erica arboreal. Rumen fluid was obtained before the morning feed and filtered through four gauze layers. Samples of $(250 \pm 10$ mg) diets were weighed into F57 Ankom bags with a pore size of $25 \mu \mathrm{m}$, heat-sealed and then placed into an incubation jar. In each digestion jar they were incubated a replica at random of each one of those ages of these species and a bag like white, with the purpose of generating the correction factor for the possible entrance of particles or loss of weight of the bags. The procedure was carried out on four replicate. Nine bags per treatment were used. Samples were incubated at $39^{\circ} \mathrm{C}$ at constant levels of agitation and rotation. After $48 \mathrm{~h}$ of incubation the jars were emptied and the bags were rinsed with cold water and dried in an oven at $105^{\circ} \mathrm{C}$. Thereafter, was determined to estimate true digestibility (TD).

\section{In situ digestibility}

In situ dry matter digestibility (ISDMD) was determined using the nylon bag technique Ørskov [10]. Samples were ground using a $2 \mathrm{~mm}$ screen and about $4 \mathrm{~g}$ of sample was weighed into nylon bags $(12 \times 10 \mathrm{~cm}$; pore size of $40 \mu \mathrm{m})$, which were introduced before the morning feeding and incubated in duplicate inside the rumen of each sheep for $72 \mathrm{~h}$. Upon removal, bags were soaked in cold water for 15 minutes to stop the microbial activity, and then frozen 
at $-30^{\circ} \mathrm{C}$ for $24 \mathrm{~h}$ to remove any microbial cells adhering to the particles. The bags were defrosted in a fridge at $4^{\circ} \mathrm{C}$, washed with cold water, oven dried at $60^{\circ} \mathrm{C}$ for $48 \mathrm{~h}$ and weighed to estimate DM disappearance. Afterwards, the residues were analyzed to calculate $\mathrm{NDF}, \mathrm{ADF}$ and CP digestibility. Organic matter digestibility (OMD) was estimated according to Aumont et al. [11] and metabolizable energy (ME) and net energy for lactation (NEL) was calculated according to Caceres and Gonzalez [12].

\section{Statistical Analysis and Calculations}

An analysis of variance of double classification and comparison of submultiple ranges was used. For the normal distribution of the data, Kolmogorov-Smirnov tests Massey [13] and the homogeneity of the variances Bartlett [14] was performed.

\section{Results}

As can be seen in Table 1, the chemical composition of the Jatropha curcas, the dry matter content, NDF, ADF, ADL, increase with age with its best results at 180 days with 26.75; 48.69; 32.85 and 20.47\%; while the CP and cellular content decrease with their highest results at 60 days 24.32 and $57.44 \%$ respectively. On the other hand, minerals showed a very variable behavior. During the dry season, the chemical composition of the Jatropha curcas Table 2 maintained a similar behavior to the rainy season, but with different values, the dry matter content, NDF, ADF, ADL, increased with age with its best results. 180 days with 28.82; 51.53; 33.44 and $20.22 \%$; while the CP and cellular content decrease with their highest results at 60 days 27.78 and $58.79 \%$ respectively. On the other hand, minerals showed a very variable behavior. The highest energy contribution and digestibility percentage at 60 days of age (Table 3) with a decrement for IVDMD, TD, ISDMD, ME and NLE of $11.04 ; 7.40 ; 8.90 \% ; 1.58$ and $1.11 \mathrm{MJ} / \mathrm{kg}$ up to 180 days, respectively, is due to differences in tissue types and characteristics independently of each plant, since depending on the constitution of the cell wall, its digestibility varies; From $100 \%$ in mesophilic cells to $0 \%$ in the xylem, this variation occurs in different tissues within a part of the plant and between similar tissues in different forage species. During the dry season, the contribution of energy and digestibility (Table 4) maintained a similar behavior to the rainy season, with a decrease of $1.52,4.63,44.26$ percentage units for IVDMD, TD, ISDMD and 0.2, $0.15 \mathrm{MJ} / \mathrm{Kg}$ of dry matter for ME and NLE. Regarding the behavior of polyphenolic compounds during the rain (Table 5), these increase with age with the best results at 180 days with 11.26, 21.10,113.93, 111.49 and $2.46 \mathrm{~g} / \mathrm{Kg}$, respectively; for total tannin, total phenol, TCT, TCTA and FCT. While during the low rainfall these indicators also showed an increase of $10.55,0.56$, $32.14,31.03$ and $1.12 \mathrm{~g} / \mathrm{Kg}$, respectively from 60 to 180 days for total tannins, total phenols, total condensed tannins, total bound condensed tannins and free condensed tannins (Table 6).

Table 1: Chemical composition of the Jatropha curcas during rainy season.

\begin{tabular}{|c|c|c|c|c|c|c|c|c|c|c|c|c|}
\hline $\begin{array}{l}\text { Age } \\
\text { (day) }\end{array}$ & $\begin{array}{l}\text { MD } \\
\text { (\%) }\end{array}$ & $\begin{array}{l}\text { CP } \\
\text { (\%) }\end{array}$ & $\begin{array}{l}\mathrm{Ca} \\
(\%)\end{array}$ & $\begin{array}{c}P \\
(\%)\end{array}$ & $\begin{array}{l}\mathrm{Mg} \\
(\%)\end{array}$ & $\begin{array}{c}\mathrm{Si} \\
(\%)\end{array}$ & $\begin{array}{l}\text { NDF } \\
(\%)\end{array}$ & $\begin{array}{l}\text { ADF } \\
(\%)\end{array}$ & $\begin{array}{l}\text { ADL } \\
\text { (\%) }\end{array}$ & $\begin{array}{l}\text { CEL } \\
(\%)\end{array}$ & $\begin{array}{l}\text { HCEL } \\
\text { (\%) }\end{array}$ & $\begin{array}{l}\text { CC } \\
(\%)\end{array}$ \\
\hline 60 & $17.5 \mathrm{c}$ & $24.32 \mathrm{a}$ & $2.41 \mathrm{~b}$ & $0.016 \mathrm{a}$ & $0.67 \mathrm{c}$ & $3.00 \mathrm{~b}$ & $42.56 c$ & $26.24 \mathrm{c}$ & $6.92 \mathrm{c}$ & $19.51 \mathrm{c}$ & 16.12 & $57.44 \mathrm{a}$ \\
\hline 120 & $22.09 \mathrm{~b}$ & $16.64 \mathrm{~b}$ & $2.89 a$ & $0.011 \mathrm{a}$ & $0.92 \mathrm{a}$ & $4.62 \mathrm{a}$ & $45.25 b$ & $28.64 b$ & $16.38 \mathrm{~b}$ & $12.26 \mathrm{~b}$ & 16.61 & $54.75 b$ \\
\hline 180 & $26.75 a$ & $16.66 \mathrm{~b}$ & $2.74 \mathrm{a}$ & $0.006 \mathrm{~b}$ & $0.86 \mathrm{~b}$ & $2.66 c$ & $48.69 a$ & $32.85 a$ & $20.47 a$ & $12.38 \mathrm{a}$ & 15.84 & $51.31 \mathrm{c}$ \\
\hline $\mathrm{SE} \pm$ & 1.456 & 0.459 & 0.014 & 0.003 & 0.001 & 0.43 & 2.789 & 1.369 & 0.963 & 0.753 & 0.843 & 1.493 \\
\hline
\end{tabular}

Table 2: Chemical composition of the Jatropha curcas during dry season.

\begin{tabular}{|c|c|c|c|c|c|c|c|c|c|c|c|c|}
\hline $\begin{array}{l}\text { Age } \\
\text { (day) }\end{array}$ & $\begin{array}{l}\text { MD } \\
(\%)\end{array}$ & $\begin{array}{l}\text { CP } \\
\text { (\%) }\end{array}$ & $\begin{array}{l}\text { Ca } \\
\text { (\%) }\end{array}$ & $\begin{array}{c}\text { P } \\
\text { (\%) }\end{array}$ & $\begin{array}{l}\text { Mg } \\
(\%)\end{array}$ & $\begin{array}{c}\mathrm{Si} \\
(\%)\end{array}$ & $\begin{array}{l}\text { NDF } \\
(\%)\end{array}$ & $\begin{array}{l}\text { ADF } \\
\text { (\%) }\end{array}$ & $\begin{array}{l}\text { ADL } \\
\text { (\%) }\end{array}$ & $\begin{array}{l}\text { CEL } \\
\text { (\%) }\end{array}$ & $\begin{array}{c}\text { HCEL } \\
\text { (\%) }\end{array}$ & $\begin{array}{l}\text { CC } \\
(\%)\end{array}$ \\
\hline 60 & $20.04 \mathrm{c}$ & $27.78 \mathrm{a}$ & $2.27 \mathrm{~b}$ & $0.015 a$ & $0.62 \mathrm{a}$ & $4.95 \mathrm{a}$ & $43.41 \mathrm{c}$ & $24.96 c$ & $8.08 c$ & $16.34 \mathrm{a}$ & $21.79 a$ & $58.79 a$ \\
\hline 120 & $25.12 b$ & $21.65 b$ & $2.62 \mathrm{a}$ & $0.010 \mathrm{~b}$ & $0.46 \mathrm{c}$ & $4.84 \mathrm{a}$ & $48.42 \mathrm{~b}$ & $30.93 b$ & $15.82 \mathrm{~b}$ & $15.08 \mathrm{a}$ & $17.45 \mathrm{~b}$ & $51.55 b$ \\
\hline 180 & $28.82 a$ & $19.84 \mathrm{c}$ & $2.05 c$ & $0.013 a$ & $0.57 \mathrm{~b}$ & $4.27 \mathrm{~b}$ & $51.53 \mathrm{a}$ & $33.44 a$ & $20.22 \mathrm{a}$ & $13.14 \mathrm{~b}$ & $18.14 \mathrm{~b}$ & $48.38 c$ \\
\hline $\mathrm{SE} \pm$ & 1.664 & 0.743 & 0.009 & 0.001 & 0.001 & 0.519 & 3.126 & 1.489 & 1.003 & 0.963 & 1.489 & 1.963 \\
\hline
\end{tabular}

a.b.c Means with different superscript in file differ at $(p<0.05)$ 
Table 3: Digestibility and energy intake of Jatropha curcas during the rainy season.

\begin{tabular}{|c|c|c|c|c|c|}
\hline $\begin{array}{c}\text { Age } \\
\text { (day) }\end{array}$ & $\begin{array}{c}\text { IVDMD } \\
\mathbf{( \% )}\end{array}$ & $\begin{array}{c}\text { TD } \\
\mathbf{( \% )}\end{array}$ & $\begin{array}{c}\text { ISDMD } \\
\mathbf{( \% )}\end{array}$ & $\begin{array}{c}\text { ME } \\
\mathbf{( M J / K g )}\end{array}$ & $\begin{array}{c}\text { NEL } \\
\text { (MJ/Kg) }\end{array}$ \\
\hline 60 & $73.37 \mathrm{a}$ & $82.77 \mathrm{a}$ & $87.85 \mathrm{a}$ & $10.86 \mathrm{a}$ & $6.59 \mathrm{a}$ \\
\hline 120 & $70.86 \mathrm{~b}$ & $81.69 \mathrm{~b}$ & $85.17 \mathrm{~b}$ & $10.51 \mathrm{a}$ & $6.35 \mathrm{a}$ \\
\hline 180 & $62.33 \mathrm{c}$ & $75.37 \mathrm{c}$ & $78.95 \mathrm{c}$ & $9.28 \mathrm{~b}$ & $5.48 \mathrm{~b}$ \\
\hline $\mathrm{SE} \pm$ & 1.359 & 0.289 & 0.789 & 0.045 & 0.0357 \\
\hline
\end{tabular}

Table 4: Digestibility and energy intake of Jatropha curcas during the dry season.

\begin{tabular}{|c|c|c|c|c|c|}
\hline $\begin{array}{c}\text { Age } \\
(\mathrm{day})\end{array}$ & $\begin{array}{c}\text { IVDMD } \\
(\%)\end{array}$ & $\begin{array}{c}\text { TD } \\
(\%)\end{array}$ & $\begin{array}{c}\text { ISDMD } \\
(\%)\end{array}$ & $\begin{array}{c}\text { ME } \\
(\mathrm{MJ} / \mathrm{Kg})\end{array}$ & $\begin{array}{c}\text { NEL } \\
(\mathrm{MJ} / \mathrm{Kg})\end{array}$ \\
\hline 60 & $70.30 \mathrm{a}$ & $82.79 \mathrm{a}$ & $85.49 \mathrm{a}$ & $10.41 \mathrm{a}$ & $6.28 \mathrm{a}$ \\
\hline 120 & $68.92 \mathrm{~b}$ & $79.44 \mathrm{~b}$ & $44.13 \mathrm{~b}$ & $10.23 \mathrm{ab}$ & $6.15 \mathrm{ab}$ \\
\hline 180 & $68.78 \mathrm{c}$ & $78.16 \mathrm{c}$ & $41.23 \mathrm{c}$ & $10.21 \mathrm{~b}$ & $6.13 \mathrm{~b}$ \\
\hline $\mathrm{SE} \pm$ & 0.29 & 0.4803 & 4.903 & 0.0407 & 0.0287 \\
\hline
\end{tabular}

Table 5 : Polyphenol content of the Jatropha curcas during the rainy season.

\begin{tabular}{|c|c|c|c|c|c|}
\hline $\begin{array}{c}\text { Age } \\
\text { (day) }\end{array}$ & Total tannins & $\begin{array}{c}\text { Total phenol } \\
\text { (g/Kg) }\end{array}$ & TCT & TCTA & FCT \\
\hline 60 & $6.57 \mathrm{c}$ & $11.35 \mathrm{c}$ & $65.11 \mathrm{c}$ & $63.17 \mathrm{c}$ & $1.94 \mathrm{~b}$ \\
\hline 120 & $7.86 \mathrm{~b}$ & $12.83 \mathrm{~b}$ & $72.37 \mathrm{~b}$ & $70.78 \mathrm{~b}$ & $1.58 \mathrm{c}$ \\
\hline 180 & $11.26 \mathrm{a}$ & $21.10 \mathrm{a}$ & $113.93 \mathrm{a}$ & $111.49 \mathrm{a}$ & $2.46 \mathrm{a}$ \\
\hline $\mathrm{SE} \pm$ & 0.479 & 1.04 & 5.226 & 5.04 & 0.086 \\
\hline
\end{tabular}

Table 6:Polyphenol content of the Jatropha curcas during the dry season.

\begin{tabular}{|c|c|c|c|c|c|}
\hline $\begin{array}{c}\text { Age } \\
\text { (day) }\end{array}$ & Total tannins & $\begin{array}{c}\text { Total phenol } \\
\text { (g/Kg) }\end{array}$ & TCT & TCTA & FCT \\
\hline 60 & $24.15 \mathrm{c}$ & $47.33 \mathrm{~b}$ & $65.89 \mathrm{c}$ & $64.29 \mathrm{~b}$ & $1.59 \mathrm{c}$ \\
\hline 120 & $29.99 \mathrm{~b}$ & $40.19 \mathrm{c}$ & $66.49 \mathrm{~b}$ & $64.60 \mathrm{~b}$ & $1.88 \mathrm{~b}$ \\
\hline 180 & $34.70 \mathrm{a}$ & $47.89 \mathrm{a}$ & $98.03 \mathrm{a}$ & $95.32 \mathrm{a}$ & $2.71 \mathrm{a}$ \\
\hline $\mathrm{SE} \pm$ & 1.047 & 3.642 & 0.8507 & 3.531 & 0.1145 \\
\hline
\end{tabular}

a.b.c Means with different superscript in file differ at $(\mathrm{p}<0.05)$.

\section{Discussion}

This behavior was given Tables $1 \& 2$ among other aspects by the aging of the plant and with it the increase of the structural components of this or that was related reduction of the synthesis of protein compounds, to the decrease of the amount of leaves, to the increase of the fraction stem and increase in the synthesis of structural carbohydrates (cellulose, hemicellulose and lignin) Verdecia et al. [15]. The decrease in protein levels with age may be related to the reduction of the synthesis of protein compounds, due to the decrease in the number of leaves and increase in the proportion of stems Verdecia et al. [16]. The levels reached in this investigation are comparable to the concentrations in most of the trees used in the tropics Pedraza et al. [17], specifically, are higher than the values obtained Garcia et al. [18,19], when evaluating different cultivars of this species and similar to those obtained by Verdecia et al. [20] in the Cauto Valley; For this reason, the evaluated species can be used as a protein supplement in ruminant diets. The fluctuations found in the minerals $(\mathrm{Ca}, \mathrm{Si})$ in both climatic seasons of this species in the present study, in calcium are consistent with those reported for numerous [21]forage trees Garcia et al. [19]. On the other hand, the silica values are similar to those obtained by Parra et al. [22] in tropical legumes. This response pattern could be attributed according to Chavez et al. [23] and Verdecia et al. [24] to the variability of the soil-climatic conditions (solar radiation, temperature, rainfall and soil) aspects that influence the assimilation and distribution in the different parts of the plants, and changes in the concentration of these elements are encouraged. The increase in Si, ADF, ADL and cell wall with age could be related to the physiological and anatomical changes that occur as the plant ages, which causes a decrease in the proportion of cytoplasmic content, cell lumen is reduced with its components soluble and increase fibrous compounds Nogueira-Filho et al. [25]. This is accentuated as the DM increases, due to the water balance of the plant and the amount of nitrogen available in the soil, among other factors.

On the other hand, Ramirez et al. [26] stated that depending on the type of tissue, as the cell of the plant matures, the cell wall widens and, commonly, produces a secondary wall of different composition, with notable deposition of aromatic constituents, so chemical and anatomical changes that affect digestibility. This was related to the fact that in the younger ages there is greater succulence of the leaves and a high amount of tender stems Bayoli et al. [27]. Hence, at an early age these species presented high percentages of digestibility. Degradability differences Tables 3 \& 4 could be associated with the characteristics of each species and genus. The relationship between chemical indicators and ruminal degradability must be kept in mind, which has been described by numerous authors for various legumes Pedraza et al. [28]. The low percentages of IVDMD and ISDMD could be attributed to the concentration of NDF, ADL and Si sufficient to modify the attack of ruminal microorganisms on plant cells, as was demonstrated by Valenciaga [29] in C. purpureus and that could be valid for legumes. Subsequently Verdecia et al. [20] reaffirmed this principle in Lotus uliginosus, Tithonia diversifolia, Erythrina variegata, Gliricidia sepium and Leucaena leucocephala. In this sense, Garcia [30]states that digestibility is due to the characteristics of the material of origin, age, phenology and period of the year, since these factors have a decisive influence on the tenors of the fibrous components. 
These results corroborate what was stated by Harborne [31], Labrada et al. [32] and Garcia [30], where the appearance of secondary compounds is related to the age of the material Tables $5 \& 6$, the defense mechanisms of the plant and the effects of soil and climate. Santacoloma-Varon and Granados [33] in this species found low amount of tannins, which could be related to the fact that the samples were taken during the dry season and this can affect the photosynthetic rate and consequently the synthesis of secondary metabolites. A It is necessary to take into account that, although the volume and speed of biochemical reactions may increase with temperature, most chemical reactions in plants have a characteristic thermal optimum, which decreases at both higher and lower temperatures. This is due, in the first instance, to the fact that the enzymatic activity and integrity of cell membranes are affected by extreme temperatures Sierra [34].

These results coincide with those reported by Sosa et al. [35] in L. leucocephala. However, the concentration of TT (21.49 $\mathrm{g} / \mathrm{kg}$ ) found in this group can be a positive element when fully evaluating the antinutritional characteristics of the polyphenolic fraction of this species, since they are in the range where, possibly, the ruminal ecosystem is not affected and increases the probability of overpassing protein formation and would facilitate post-renal nitrogen digestibility Aerts et al. [36], Estevez et al. [37] and Olivares et al. [38] found low levels of TT in this plant (3.01 g / kg). This behavior at an early age describes that the species with the highest proportion of fiber have a high concentration of hydroxylated metabolites, aspects that coincide with the statements made by numerous authors about the negative effect of cell wall compounds and tannins on animal nutrition Kumar [39], Makkar [7]. Chew et al. [40], found lower concentrations of TF (17 g / kg) in the leaves than in the flowers in L. leucocephala, which could be related to the process of photosynthesis and its possible accumulation Bhattacharya et al. [41].

\section{Conclusion}

The results of the present investigation evidenced the marked effect of climatic factors and age on the quality of the Jatropha curcas since, as the maturity of the forage progressed, its nutritional contribution decreased with a decrease in the $\mathrm{CP}$, the nutrient content, digestibility and energy intake, as well as an increase in the fibrous fraction and the content of polyphenolic compounds.

\section{References}

1. Venturini ME, Reyes JE, Rivera CS, Oria R, Blanco D (2011) Microbiological Quality and Safety of Fresh Cultivated and Wild Mushrooms Commercialized in Spain. Food Microbiology 28(8): 1492-1498.

2. Ranganna S (1986) Handbook of analysis and quality control for fruits and vegetable products. Tata McGraw Hill Publishing. New Delhi, India.

3. Rastogi NK, Raghavarao KSMS, Niranjan K, Knorr D (2002) Recent developments in osmotic dehydration: Method to enhance mass transfer. Food Science Technology 13(2):48-59.

4. Tonon RV, Baroni AF, Hubinges MD (2007) Osmotic Dehydration of Tomato in Ternary Solutions: Influence of Process Variables on Mass Transfer Kinetics and an Evaluation of the Retention of Arytenoids. Food Engineering 82(4): 509-517.

5. Nieto A, Castro MA, Alzamora A (2001) Kinetics of moisture transfer during air drying of blanched and/or osmotically dehydrated mango. Journal of Food Engineering 50(3): 175-185.

6. Jain SK, Verma RC, Murdia LK, Jain HK, Sharma GP (2011) Optimization of Process Parameters for Osmotic Dehydration of Papaya Cubes. Food Science and Technology 48(2): 211-217.

7. Cao T, and Yeomans JS (2016) The Calculation of Optimal Osmotic Dehydration Process Parameters for Mushrooms: A Firefly Algorithm. International Journal of Environmental and Agriculture Research 2(12): 52-58.

8. Yang XS (2010) Nature-Inspired Metaheuristic Algorithms (2 ${ }^{\text {nd }}$ Ed.); Luniver Press. Frome, UK.

9. Yang JS, Yang XS (2014) Determining Optimal Osmotic Drying Parameters Using the Firefly Algorithm. $6^{\text {th }}$ International Conference on Applied Operational Research (ICAOR). 6: 32-39.

10. Mudhar GS, Toledo RT, Floros JD, Jen JJ (1989) Optimization of carrot dehydration process using response surface methodology. Journal of Food Science 54(3): 714-719.

11. Myers RH, Montgomery DC (1995) Response Surface Methodology: Process and Product Optimization Using Designed Experiments. John Wiley and Sons, New York, USA.
This work is licensed under Creative Commons Attribution 4.0 License To Submit Your Article Click Here: Submit Article

DOI: $10.32474 /$ CIACR.2019.08.000276

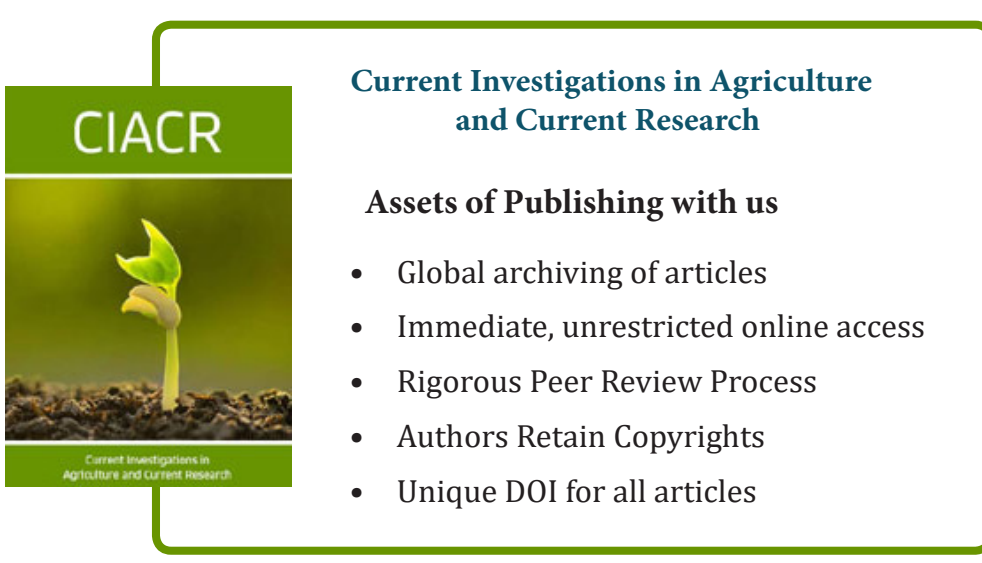

